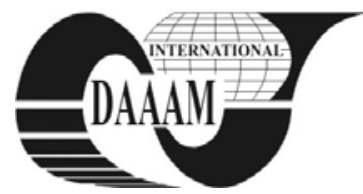

\title{
ROLLER BURNISHING APPLICATION FOR TURNED PARTS MADE OF AUSTEMPERED DUCTIL IRON
}

\author{
FERNANDEZ VALDIVIELSO, A[sier]; RODRIGUEZ, A[drian]; URBIKAIN, G[orka] \& \\ LOPEZ DE LACALLE, L[uis] N[orberto]
}

\begin{abstract}
In this paper, roller burnishing as a finishing process of revolution parts made of Austempered Ductile Iron is studied. It is a well-know material used for decades, but in the last five years its use has exponentially increased due to their mechanical properties. In this way, the reduction of time and cost of finishing operations is a necessary issue to improve the manufacturing productivity.

This work presents experimental tests using burnishing techniques after roughing operations. Different burnishing conditions have been used. Results show that the application of this technique can be of great interest, especially when eliminate the directionality pattern of turning is necessary.

Key words: roller burnishing, ADI 1000, finishing, turning, roughness directionality, mechanical treatments
\end{abstract}

\section{INTRODUCTION}

Austempered Ductil Iron (ADI) began to be used industrially in the 80 's. One of its first applications was the automotive sector for the design, manufacture and optimization of components for high-end vehicles; since then, the increase of their use has been spectacular. This is mainly because the parts made of this material show an excellent strength-to-weight ratio, improving significantly the typical values offered by aluminum alloys, steel and other castings. ADI castings offer an interesting combination of mechanical properties derived from both, a precise percentage of alloying and a controlled thermal treatment ('austempering'). ADI castings are characterized by a special microstructure of $\mathrm{Fe}-\mathrm{C}$ which must be uniformly distributed (Cakir et al., 2008; Klocke et al., 2010). The first choice for ADI removal are carbide inserts, as for the rest of ADI castings. However, ADI castings have a lower machinability than other castings, resulting in an increased tool wear due to abrasion and adhesion phenomena, which reduce tool life. In order to reduce the machining time, burnishing techniques could be feasible to eliminate semi-finishing and finishing turning operations. The idea is to maintain roughing operations and later on burnishing, achieving the final surface roughness reducing time and cost. Moreover, combining turning and burnishing in the opposite direction, it is possible to eliminate the directionality roughness pattern on turning parts. Another fact to take into account is that residual stresses are also important (Budic et al., 2007), and burnishing process introduce compression residual stresses on workpiece surface.

In this paper, roller burnishing as a suitable technique for finishing this type of components is presented. Burnishing is a simple operation, inexpensive and which generates high quality final surfaces (El-Khabeery et al., 2001; López de Lacalle et al., 2011; Radulescu et al., 2009). Roller burnishing technology applied in lathes allows finish surfaces within the quality of grinding (i.e., less than $1 \mu \mathrm{m} \mathrm{Ra}$ ). Thus, roller burnishing can replace finishing processes such as grinding, shot peening or hand polishing. In addition, burnishing is applied on the same machines, using an additional burnishing tool.

\section{BALL BURNISHING EFFECTS}

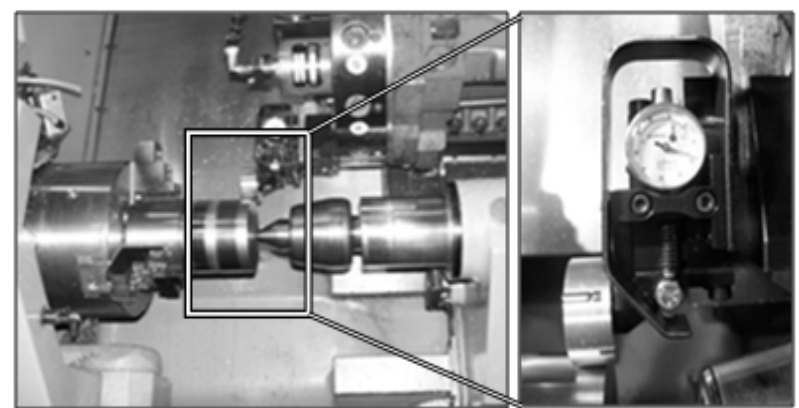

Fig. 1. (Left) Burnishing set-up, (Right) Roller burnishing tool

Burnishing is a cold-working process performed on a previously machined surface. The process is based on making small plastic deformations on part surfaces, which causes material displacement from the "peaks or ridges" to the "valleys or depressions" of surface micro-irregularities. This mechanism is performed by a rolling element (tool, a ball, or a roller) that moves close to the tool paths on the surface, applying a regular compression force at the same time.

The 'crushing' causes four effects on the surface:

- Reduction of surface roughness in more than an order of magnitude. The final quality is similar to grinding, even reaching a mirror-like aspect.

- Generation of high compression residual stresses on workpiece surface, which is beneficial for the fatigue behaviour of the component. Moreover, the absence of heat produced by this mechanical surface treatment prevents metallurgical changes on surfaces.

- Surface hardness increment between $30 \%-60 \%$ (HBN) in common steels.

- Dimensional tolerances are kept $(<0.01 \mathrm{~mm})$, for example in burnished holes. Special tools for hole finishing is a typical application of spring-type burnishing devices.

\section{ADI 1000 BURNISHING APPLICATION}

The cutting experiments were conducted in a CMZ TC25BTY turning center with a FANUC® 31iT HVi numeric control. The work-piece, a cylinder of ADI 1000, was rigidly clamped and machined using the established cutting conditions for roughing operations. After machining, the burnishing tests were carried out. An Ecorrol EG5-1 burnishing tools was used and the values used in tests are shown in Table 1.

\begin{tabular}{|c|c|c|c|}
\cline { 2 - 4 } \multicolumn{1}{c|}{} & \multicolumn{3}{c|}{ Burnishing levels } \\
\cline { 2 - 4 } \multicolumn{1}{c|}{} & $\mathbf{1}$ & $\mathbf{2}$ & $\mathbf{3}$ \\
\hline $\mathbf{a v}[\mathbf{m m} / \mathbf{r e v}]$ & 0.4 & 0.2 & 0.1 \\
\hline Vc[m/min] & 80 & 100 & 120 \\
\hline Force [N] & \multicolumn{3}{|c|}{1000} \\
\hline
\end{tabular}

Tab. 1. Burnishing levels used in conducting experiments 


\begin{tabular}{|c|c|c|c|c|c|}
\hline & $\begin{array}{c}\text { Force } \\
{[\mathbf{N}]}\end{array}$ & $\begin{array}{c}\mathbf{a}_{\mathbf{v}} \\
{[\mathbf{m m} / \mathbf{r e v}]}\end{array}$ & $\begin{array}{c}\mathbf{V}_{\mathbf{c}} \\
{[\mathbf{m} / \mathbf{m i n}]}\end{array}$ & $\mathbf{R a}[\mathbf{\mu m}]$ & $\mathbf{R z}[\mathbf{\mu m}]$ \\
\hline Turning & - & 0.4 & 80 & 2.12 & 11.5 \\
\hline \hline & & 0.4 & 80 & 1.16 & 7.19 \\
\cline { 3 - 6 } & & 0.4 & 100 & 1.21 & 9.97 \\
\cline { 3 - 6 } & & 0.4 & 120 & 1.02 & 6.09 \\
\cline { 3 - 6 } & & 0.2 & 80 & 0.94 & 6.74 \\
\cline { 3 - 6 } & \multirow{4}{*}{$\begin{array}{c}\text { Burnishing } \\
\text { M03 }\end{array}$} & 0.2 & 100 & 1.21 & 9.67 \\
\cline { 3 - 6 } & & 0.2 & 120 & 1.07 & 10.5 \\
\cline { 3 - 6 } & & 0.1 & 80 & 0.90 & 7.01 \\
\cline { 3 - 6 } & & 0.1 & 100 & 0.82 & 4.99 \\
\cline { 3 - 6 } & & 0.1 & 120 & 1.03 & 10.0 \\
\hline
\end{tabular}

Tab. 2. Roughness results obtained before and after burnishing M03 operation

\begin{tabular}{|c|c|c|c|c|c|}
\hline & $\begin{array}{c}\text { Force } \\
{[\mathbf{N}]}\end{array}$ & $\begin{array}{c}\mathbf{a}_{\mathbf{v}} \\
{[\mathbf{m m} / \mathbf{r e v}]}\end{array}$ & $\begin{array}{c}\mathbf{V}_{\mathbf{c}} \\
{[\mathbf{m} / \mathbf{m i n}]}\end{array}$ & $\mathbf{R a}[\mathbf{\mu m}]$ & $\mathbf{R z}[\mathbf{\mu m}]$ \\
\hline Turning & - & 0.4 & 80 & 2.12 & 11.5 \\
\hline \hline & & 0.4 & 80 & 0.92 & 7.34 \\
\cline { 3 - 6 } & & 0.4 & 100 & 1.02 & 7.44 \\
\cline { 3 - 6 } & & 0.4 & 120 & 1.17 & 9.47 \\
\cline { 3 - 6 } & & 0.2 & 80 & 0.94 & 7.7 \\
\cline { 3 - 6 } & \multirow{4}{*}{$\begin{array}{c}\text { Burnishing } \\
\text { M04 }\end{array}$} & 0.2 & 100 & 1.02 & 7.84 \\
\cline { 3 - 6 } & & 0.2 & 120 & 0.79 & 6.15 \\
\cline { 3 - 6 } & & 0.1 & 80 & 0.74 & 5.87 \\
\cline { 3 - 6 } & & 0.1 & 100 & 0.79 & 6.58 \\
\cline { 3 - 6 } & & 0.1 & 120 & 1.17 & 9.12 \\
\hline
\end{tabular}

Tab. 3. Roughness results obtained before and after burnishing M04 operation

Table 2 shows the roughness results obtained in burnishing tests; burnishing in the same rotation direction than in the previous turning (M03). However, in table 3 the rotation direction is the opposite (M04) (helix-crosses). Using this direction, eliminate the directionality pattern generated by the previous turning is possible.

Results show that roughness parameters obtained are better using helix-crosses burnishing. In both cases the final roughness is better with small values of feed per revolution. Regarding the cutting speed variation, results do not make clear the influence of this parameter on the surface quality obtained.

Figure 2 shows three 3D surface topographies. In up figure, the topography of the turned surface after roughing conditions is shown. Typical turning peaks and valleys are seen in this picture. In down right figure, the topography after burnishing M03 is shown. A decrement in surface roughness is observed, but the roughness peaks characteristic of turning are still

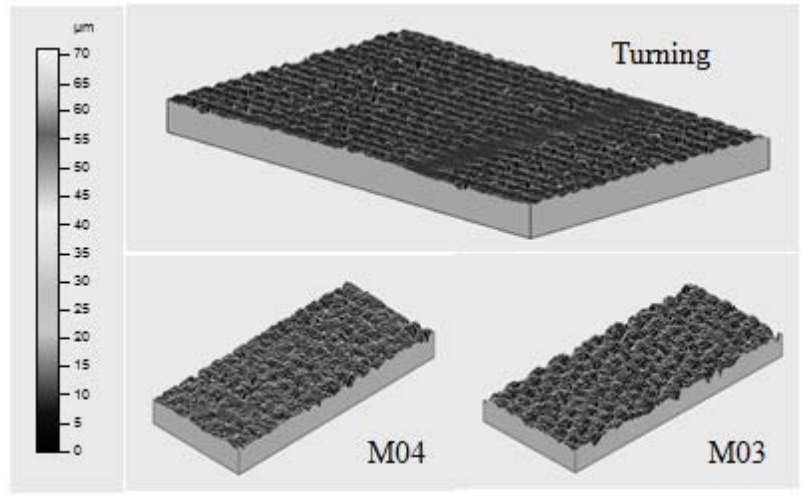

Fig. 2. (Up) 3D topography after turning operation. (Down Left) 3D topography after burnishing M04. (Down Right) 3D topography after burnishing M03, directionality patter elimination appreciated. It is in down left figure where the directionality pattern elimination is shown. In this case, helix-crosses burnishing has been used.

\section{CONCLUSIONS}

The influence of roller burnishing on ADI 1000 turned parts was investigated. Based on the experimental results achieved, the following conclusions can be stated:

- Roller burnishing process improves significantly the surface roughness of ADI 1000 turned parts.

- Combining helix-crosses burnishing and low values of feed per revolution, a high surface roughness improvement could be achieved.

- Directionality roughness pattern generated in turning operations could be eliminated.

Future work on ADI 1000 roller burnishing research should consider the following:

- Conducting additional tests using different burnishing pressure values.

- Conducting tests using ball burnishing in order to compare the finishing results.

- The use of a statistical approach to model the surface roughness parameters.

\section{ACKNOWLEDGEMENTS}

Thanks are addressed to the company Gamesa and the MuProD project. The authors would like to acknowledge the help of E. Sasia in conducting experiments.

\section{REFERENCES}

Budic, I.; Vitez, I. \& Marusic, V. (2007). Residual stresses in iron castings, Chapter 49 in DAAAM International Scientific Book 2007, B. Katalinic (Ed.), Published by DAAAM International, ISBN 3-901509-60-7, ISSN 17269687, Vienna, Austria

Cakir, M., Isik, Y. (2008). Investigating the machinability of austempered ductile irons having different austempering temperatures and times. Materials \& Design, Vol. 29 (5), pp. 937-942

El-Khabeery, M.M. and El-Axir, M.H. (2001). Experimental techniques for studying the effects of milling rollerburnishing parameters on surface integrity. Int. Journal of Machine Tools and Manufacture. Vol. 41, No. 12, pp.1705-1719

Klocke, F., Arft, M., Lung, D. (2010). Material-related aspects of the machinability of Austempered Ductile Iron. Production Engineering, Vol. 4(5), pp. 433-441

López de Lacalle, L.N., Rodriguez, A., Lamikiz, A., Celaya, A., Alberdi, R. (2011). Five-axis Machining and Burnishing of Complex Parts for the improvement of surface roughness, International Journal of Materials and Manufacturing Processes, in press.

Radulescu, M. - C.; Radulescu, B. \& Cozminca, I. (2009). Employing Experimental Plans in Plane Metal Burnishing, Annals of DAAAM for 2009 \& Proceedings of the 20th International DAAAM Symposium, 25-28th November 2009, Vienna, Austria, ISSN 1726-9679, ISBN 978-3901509-70-4, Katalinic, B. (Ed.), pp. 0539-0540, Published by DAAAM International Vienna, Vienna 